\title{
Applying an Error Reduction Model to an Injury and Illness Prevention Program- Steps to Improve an Occupational Safety and Health Management System (OSHMS)
}

\author{
Koshy Koshy, PhD \\ Rutgers School of Public Health, 300 Atrium Drive, Somerset, New Jersey \\ E-mail: koshyko@rutgers.edu \\ Michael Presutti, BA \\ Rutgers School of Public Health, 300 Atrium Drive, Somerset, New Jersey \\ Mitchel A. Rosen, PhD, CHES \\ Rutgers School of Public Health, 300 Atrium Drive, Somerset, New Jersey
}

Received: Feb. 19, $2017 \quad$ Accepted: August 8, $2019 \quad$ Published: October 1, 2019

doi:10.5296/jmr.v11i4.10775 URL: https://doi.org/10.5296/jmr.v11i4.10775

\begin{abstract}
Implementing proactive steps to control workplace hazards is the key to an effective Injury and Illness Prevention Program (IIPP). A model for an IIPP that incorporated error reduction techniques was developed by Rutgers through an OSHA Susan Harwood grant. A “user's manual" outlining various strategies, techniques, and materials necessary to successfully administer and facilitate a sustainable IIPP and a one-day training course to assist practitioners implement the program, was developed as part of this program. A follow-up study with the 118 participants who attended the training showed that they were able to more effectively organize onsite safety committees, engage workers in the Job Hazard Analysis (JHA) cycle, and develop peer mentorship programs. Latent issues including the lack of resources (time, staff, and funds) were seen as impediments to effective program deployment.
\end{abstract}

Keywords: Injury prevention, safety program, skill-based training 


\section{Macrothink}

\section{Introduction}

A holistic approach to Injury and Illness Prevention Programs (IIPP) is vital to recognizing, avoiding, and preventing errors (mistakes) that lead to undesirable events (injuries). The Bureau of Labor Statistics estimates that approximately 3.3 million serious work-related injuries and 4,821 fatalities occurred in 2014 (BLS, 2014). The human cost of preventable workplace injuries and deaths is infinite. However, according to the Insurance industry data, the direct cost of the most disabling workplace injuries and illnesses in 2007 amounted to $\$ 250$ billion in U.S. worker's compensation costs (Leigh, 2011). IIPP are universal interventions that can substantially reduce the number and severity of workplace injuries and alleviate the associated financial burdens on U.S. workplaces (Vredenburgh, 2002).

\subsection{Safety \& Health Management System}

This study identified a method to holistically look at both program management and behavioral aspects of an injury and illness prevention program to determine how best to apply means, methods, and strategies to incorporate them to an effective safety management system. Implementing such a management system may lead to many benefits (OSHA, 2012, 2015), among them:

1. For every dollar spent on an Injury and Illness Prevention Program (IIPP), an employer can expect up to six times a return on investment.

2. IIPP, especially those that incorporate effective error reduction techniques, closely parallel quality control programs and hence provide direct ancillary benefits to production.

3. Lowering insurance experience modification ratings (EMR's) through IIPP also translate into direct saving to a company.

4. Third-party contractors are often chosen on the basis of past performance that includes the degree of risk they pose to an owner/developer of host bidding for contracts.

5. An effective IIPP increases employee morale.

\subsection{How Do Errors That Cause Injuries and Illnesses Occur?}

There are numerous variables and inputs that lead to undesired events that an effective Injury and Illness Prevention Program (IIPP) can help control. Since errors are universal and may occur at every level, systems need to be flexible to include multiple users and variables. Figure I is a list of potential variables that can lead to an event.

\subsection{Error Reduction Awareness in IIPP}

Adults learn best when they learn the "nature" of a hazard and how it can cause harm (Koshy, 2015). They come to accept the "rules" more readily and require less enforcement effort because the validation is internalized and "makes sense" to the learner. Some hazards are difficult to explain because they cannot be seen or easily measured; this is the case for systemic hazards. Workers know an error when they see one yet don't necessarily know "why" and "how" we come to make errors and more importantly, how they may be reduced. 


\section{MInstitute Machink $_{\text {inth }}$}

Journal of Management Research

ISSN 1941-899X 2019, Vol. 11, No. 4

Training on how the human brain makes errors is likely to increase awareness of how workers fall into error traps. Error reduction training also demonstrates how an effective IIPP takes much of the guesswork out by collectively anticipating problems and formulating programs, sequences, hazard identifications, controls and means and methods.

Figure II is a depiction of weaknesses from working without a systematic error reduction program detailing how workers (employers, managers, and workers) make mistakes (errors) and how to reduce them through planned programs. Such pedagogical demonstrations, all based on established science, allow employers and employees to better understand the necessity of these programs and "buy in" to the concepts because the science validates theory (USDOE, 2009).

\begin{tabular}{|c|c|c|c|}
\hline $\begin{array}{l}\text { SYSTEMS } \\
\text { Strategic vision, Defined } \\
\text { and well defined proced } \\
\text { Anticipated demands of } \\
\text { Goals, Well Defined Role } \\
\text { Management commitm } \\
\text { Multilateral Communica }\end{array}$ & $\begin{array}{l}\text { objectives, Clear concise } \\
\text { ures. Time pressures, } \\
\text { task, Multiple Tasks or } \\
\text { es and Responsibilities, } \\
\text { ent Guidance, Complexity, } \\
\text { tions, Sensitivity, Importance }\end{array}$ & $\begin{array}{l}\quad \text { MATERIALS } \\
\text { Chemical, Dynamic } \\
\text { State of Matter, } \\
\text { Physical, Health } \\
\text { (GHS) Biological } \\
\text { Properties Weight } \\
\text { Stability, Reactivity }\end{array}$ & $\begin{array}{l}\quad \text { EQUIPMENT } \\
\text { Appropriate, Properly } \\
\text { Maintained, Ease of } \\
\text { Use, Availability of } \\
\text { Parts, Layout, Inherent } \\
\text { Dangers, Improvised } \\
\text { Ergonomics }\end{array}$ \\
\hline $\begin{array}{l}\text { PEOPLE } \\
\text { Skill Level } \\
\text { Unfamiliar } \\
\text { Inexperienced } \\
\text { Aptitude } \\
\text { Communication } \\
\text { difficulties } \\
\text { Attitude, Fitness of } \\
\text { Duty Personal Travails } \\
\text { Manual Dexterity } \\
\text { Personality, Stress } \\
\text { Complacency, } \\
\text { Overconfidence } \\
\text { Inaccurate Risk } \\
\text { Perception, Overly } \\
\text { Ambitious, } \\
\text { Limited Attention Span, } \\
\text { Bias or Prejudice }\end{array}$ & & & $\begin{array}{l}\text { ENVIRONMENT } \\
\text { Extreme Heat } \\
\text { Extreme Cold } \\
\text { Weather/Climate } \\
\text { Visibility, Noise } \\
\text { Darkness } \\
\text { Fast-paced/Delays } \\
\text { in Time, Hostile } \\
\text { Surrounding } \\
\text { Departure from } \\
\text { Routine, } \\
\text { Unfamiliar } \\
\text { Surroundings } \\
\text { Distractions and } \\
\text { interruptions, } \\
\text { Fear of Error, } \\
\text { Clutter, Disorder } \\
\text { Stressful, Chaotic }\end{array}$ \\
\hline
\end{tabular}

Figure I. Holistic Approach to Error Reduction 


\section{Macrothink}

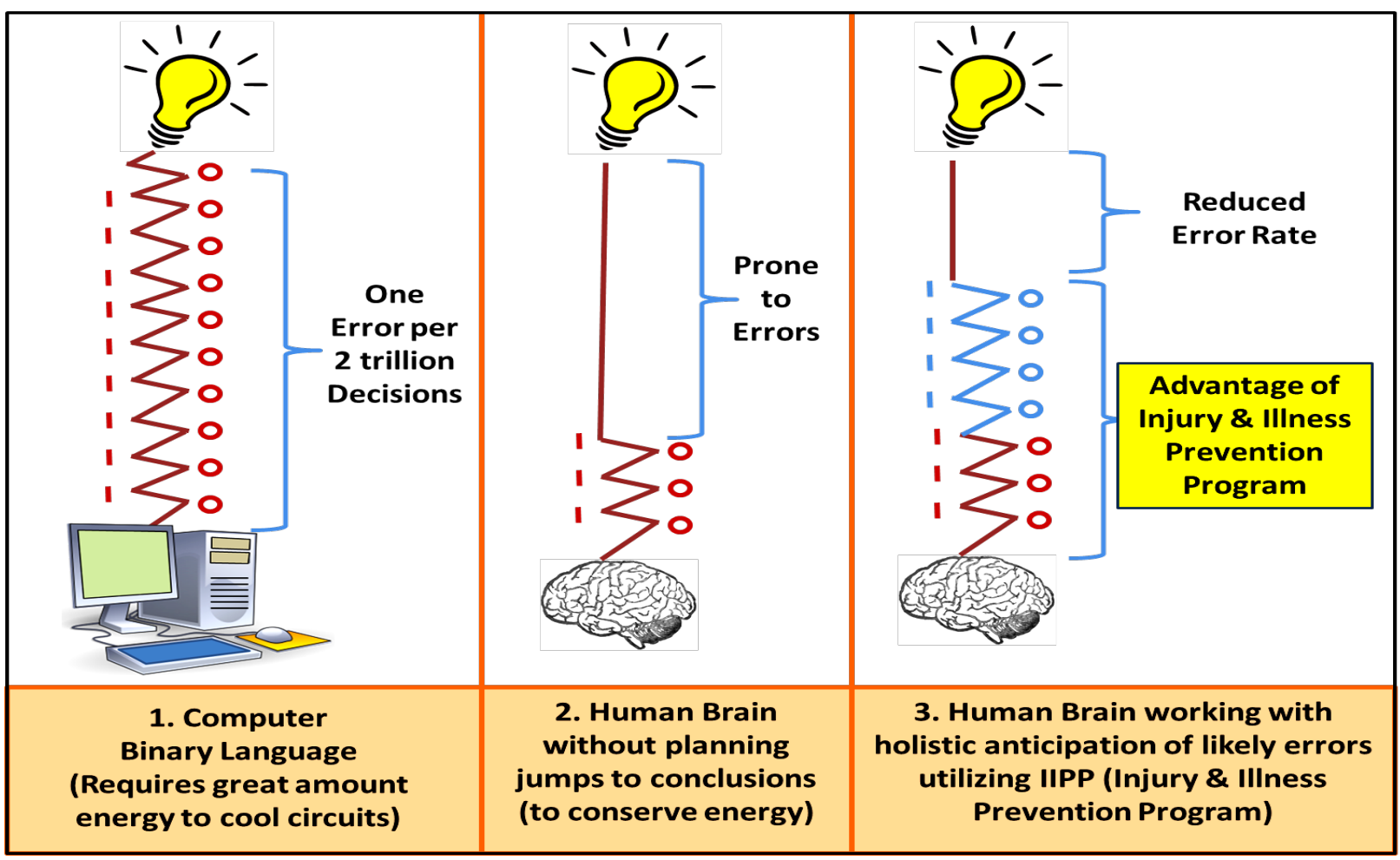

Figure II. Behavioral Side of IIPP

\section{Method}

A one-day Applying Error Reduction Platform to Injury and Illness Prevention Program course was offered to assist workers develop an Injury and Illness Prevention Program for their jobsite. This training focused on how error reduction tools can be used to assist workers realize how errors occur at the job site. Further, the training provided strategies to conducting an effective Job Hazard Analysis (JHA), host safety \& health committee meetings, and foster peer-mentorship programs. Syllabus and materials developed for the program can be accessed at (http://ophp.sph.rutgers.edu/error.zip).

An online survey was administered to the students who completed the one-day training, approximately one year to 18 months after the training. The survey attempted to ascertain how the training prepared participants to implement error reduction tools to the Safety and Health Management System at their worksite. They were queried on their efforts to train workers and the progress and experience of implementing an IIPP. Data analysis yielded descriptive statistics about the survey participants, including state of employment, worker training experience and years of occupational safety and health experience.

\section{Results}

Surveys were distributed to all 118 participants who attended the training. A total of 41 program participants attempted the survey (35.7\%). Respondents reported that they were employed in New Jersey, New York, or Pennsylvania. Thirty-two of the participants reported that they were safety trainers, managers, supervisors, safety committee members, hired safety consultants, and nine participants skipped the questions. Based on the authors' interaction 
with the class, we know that all 118 participants were involved with worker safety. Additionally, from classroom interaction, we know that the majority of them did not have a safety management system in place before this training.

A series of questions were posed related to the effectiveness of implementing the error reduction tools for developing JHA's, setting up safety committees, and fostering-mentorship programs along with applied strategies for worker recognition. These results are summarized in Table 1.

Thirty-five of the participants reported that they had a process in place to periodically review their written records including JHA's, while three reported they did not and the other three skipped this question. When asked if their workers "participated in this process," 27 of the respondents stated that they did and the other 11 skipped the question. When asked if they created site-specific questionnaires, 18 of the respondents said "yes" 20 said "no" and three skipped the question. Twenty-eight of the participants acknowledged that they conducted routine hazard analysis at the worksite, 10 said they did not and three skipped the question.

Table 1. Effectiveness of implementing an Injury and Illness Prevention Program (IIPP)

\begin{tabular}{|l|l|l|l|}
\hline Question & Yes & No & Skipped \\
\hline Do you have a process in place to periodically review written safety records? & 35 & 3 & 3 \\
\hline Do workers participate in the inspection process? & 27 & 0 & 14 \\
\hline $\begin{array}{l}\text { Have you created questionnaires for site specific tasks to assess skillsets of } \\
\text { your workers? }\end{array}$ & 18 & 20 & 3 \\
\hline Are routine Job Hazard Analysis (JHA) conducted at your worksite? & 28 & 10 & 4 \\
\hline $\begin{array}{l}\text { Are workers periodically interviewed, to solicit feedback on challenges they } \\
\text { face, while carrying out their tasks? }\end{array}$ & 27 & 9 & 5 \\
\hline Do you have a safety committee at your workplace? & 29 & 6 & 6 \\
\hline Do you have regularly scheduled safety meetings? & 29 & 1 & 11 \\
\hline Do you have a peer-mentorship program at your worksite? & 16 & 19 & 6 \\
\hline $\begin{array}{l}\text { Does your worksite have a process to recognize/reward workers for } \\
\text { contributions to safety? }\end{array}$ & 22 & 11 & 8 \\
\hline
\end{tabular}

Open-ended questions were posed related to their efforts in engaging workers in the JHA process, safety committees, and providing peer-mentorship. The successes and challenges they identified are summarized in Table 2. 
Table 2. Engaging Workers to Identify Workplace Hazards

\begin{tabular}{|c|c|c|}
\hline Activity & Success Identified & Limitation Recognized \\
\hline $\begin{array}{l}\text { Involving workers in creating } \\
\text { JHA's and participating in } \\
\text { routine inspections }\end{array}$ & 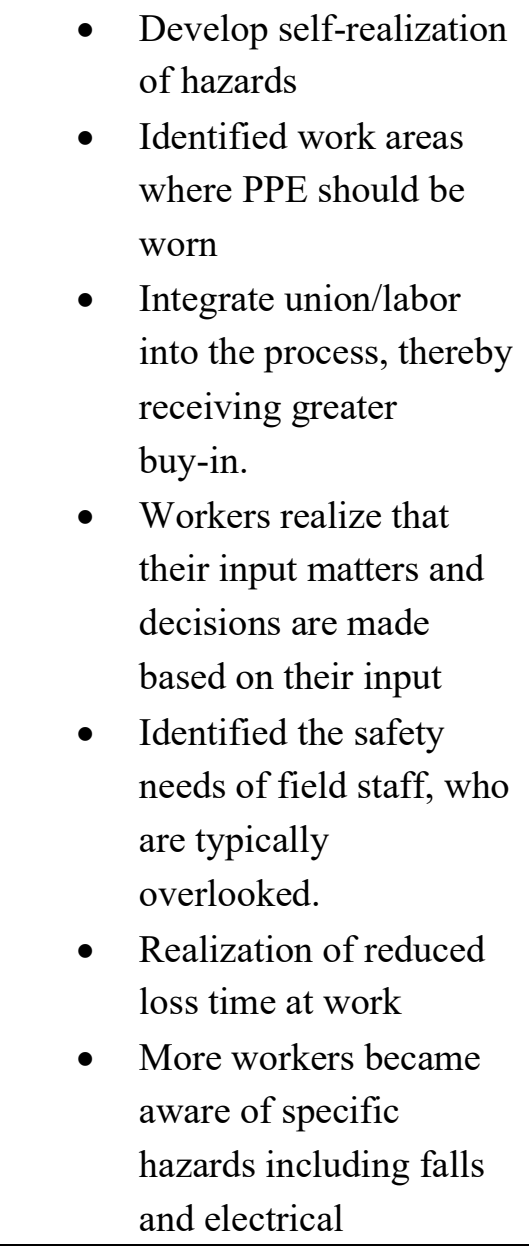 & $\begin{array}{l}\text { - Need to keep up energy } \\
\text { level for consistency } \\
\text { - Using JHA checklists } \\
\text { provided by insurance. } \\
\text { They tend to be generic. } \\
\text { Lot of repetition } \\
\text { - Lack resource allocation } \\
\text { (time, money, and staff) } \\
\text { - Consultant, working } \\
\text { with small businesses. } \\
\text { Not enough time with } \\
\text { the workers }\end{array}$ \\
\hline Having a safety committee & $\begin{array}{l}\text { Discuss recent accidents } \\
\text { and countermeasures to } \\
\text { prevent them } \\
\text { - Process changes were } \\
\text { implemented based on } \\
\text { suggestions } \\
\text { - Committee input used } \\
\text { as support argument for } \\
\text { purchasing upgraded } \\
\text { equipment } \\
\text { Reviewed recent } \\
\text { injuries and addressed } \\
\text { preventative measures } \\
\text { Having maintenance } \\
\text { personnel on the safety } \\
\text { team is very beneficial. } \\
\text { They are the first to be } \\
\text { aware of many issues. }\end{array}$ & 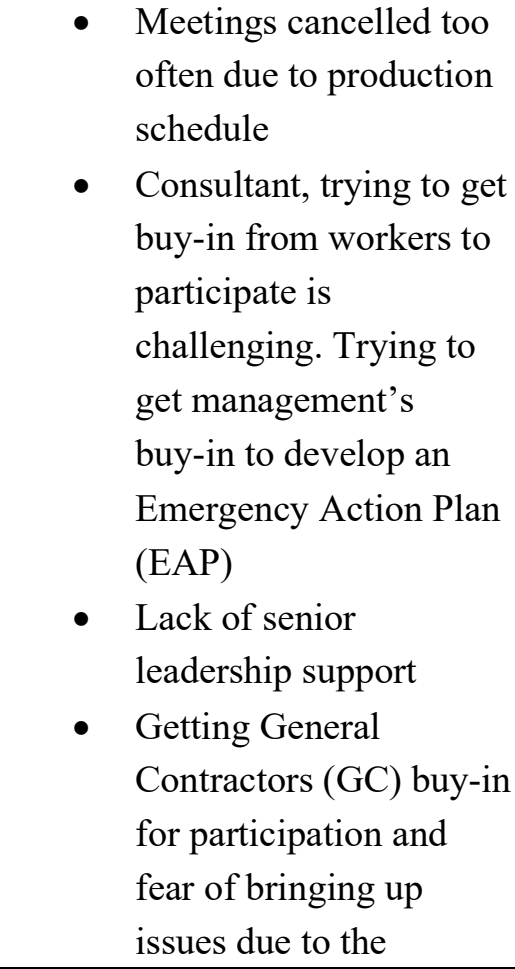 \\
\hline
\end{tabular}




\begin{tabular}{|c|c|c|}
\hline & $\begin{array}{l}\text { - Committee drives the } \\
\text { Safety Data Sheet } \\
\text { (SDS) acquisition and } \\
\text { filing } \\
\text { - Training needs } \\
\text { addressed }\end{array}$ & $\begin{array}{l}\text { potential of retaliation } \\
\text { from GC by not inviting } \\
\text { to participate in future } \\
\text { projects } \\
\text { - Lack of } \\
\text { resources/mainly time }\end{array}$ \\
\hline Peer Mentorship & 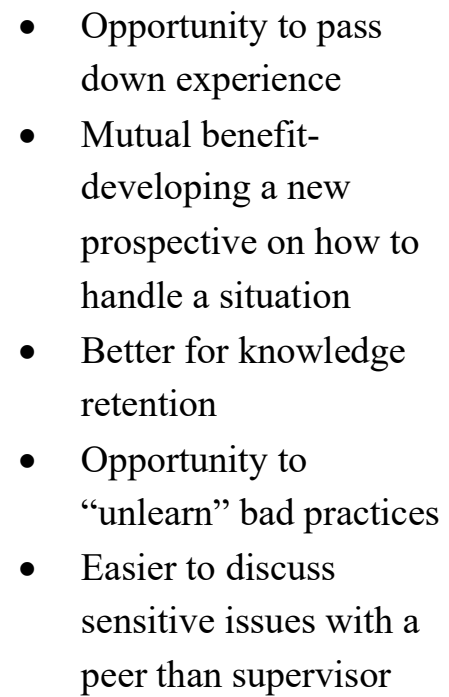 & $\begin{array}{l}\text { - Leadership's failure to } \\
\text { understand the benefits } \\
\text { of mentorship. } \\
\text { - Bad habits passed down } \\
\text { - Time allocation } \\
\text { - Lack of experienced } \\
\text { workers due to high } \\
\text { turnover }\end{array}$ \\
\hline
\end{tabular}

Once the workplace hazards are identified, it's important to train workers on safe work practices to control these hazards (OSHA, 2015). Participants were queried on the skills they felt their workers needed to develop, based on implementing the error reduction program, and limitations they encountered while attempting to meet them. Table 3 is a list of safety and health skill-based courses identified by these participants for their workers. It should also be noted that the majority of the respondents listed providing the OSHA Outreach Training to their workers. As the outreach program is more of an awareness level training, and required in these jurisdictions, they were not included with the results (NYSDOL, 2008).

Table 3. Safety Training Offered Beyond Awareness/Outreach Training

\begin{tabular}{|c|c|c|}
\hline Needed Training & Determining which Workers Attend & Limitation \\
\hline $\begin{array}{ll}\text { - } & \text { Confined Space } \\
\text { - Scaffold First } \\
\text { - } \text { aid-CPR } \\
\text { - Risk from } \\
\text { - } \text { chemicals } \\
\text { - Electrical safety } \\
\text { - Lockout/Tagout } \\
\text { Ergonomics }\end{array}$ & $\begin{array}{l}\text { - } \\
\text { Everyone who wears PPE } \\
\text { receives training } \\
\text { - } \text { Based on JHA Review } \\
\text { - } \text { function to training } \\
\text { Training based on job bid } \\
\text { specifications/jurisdiction }\end{array}$ & $\begin{array}{l}\text { - Lack of follow-up } \\
\text { training } \\
\text { - Funding } \\
\text { - Time away from work } \\
\text { - Language barriers }\end{array}$ \\
\hline
\end{tabular}

\section{Discussion:}

This study investigated how the interaction of the people within the system can be improved by enfranchising them to take ownership of their health and safety. Trainees who completed 
the error reduction course were able to take the materials back to their worksite and our study identified a limited number of gains they realized.

\subsection{Job Hazard Analysis}

Having workers take ownership and involving them in the process of conducting a JHA is an important part of safety and health management. In addition to improving the overall safety and health of the workplace, this study showed that employees developed self-realization for the need to wear personal protective equipment while performing select tasks and identified hazardous worksite conditions that may lead to injuries including falls and electrocution. Interestingly, respondents also reported that workers identified the need for additional resources including personal protective equipment and training from participating in the JHA inspections.

Checklists are an important tool for worksite safety \& health management. However, if they are not specific to the tasks, they may be ineffective. When asked what resources they have to assist with inspections, several participants mentioned having checklists. Further, respondents reported that the checklists provided by their insurance carrier were ineffective as they were generic and not pertinent to their tasks. Not having the resources for creating and updating the checklists may have been the reason for using them. Although these checklists are a good starting point, they are not sufficient for site-specific details.

Several respondents reported that they were safety consultants to small businesses (construction and general industry). Their main challenge was that they didn't have the sufficient time to interact with the workers to identify issues with their safety management system. Many of the study participants were safety consultants in New York City, a jurisdictional requiring a site safety manager presence on active construction projects and when other identified hazards are present (NYCDOB, 2016). As this study did not investigate the size of the business, in relation to having a OSHMS, it's challenging to draw a conclusion from these comments. However, it is evident that employers are reluctant to commit funds for safety initiatives beyond mandated requirements.

\subsection{Safety Committee}

Twenty-nine of the respondents reported having a safety committee in place at their worksite and fifteen of them had monthly meetings. A wide range of objectives were met through these meetings. The most commonly reported outcome was that they discussed recent accidents and possible countermeasures for their prevention. They also met specific timely objectives including updating their Safety Data Sheets. Participants also described the importance of having representation from a cross section of the workforce including maintenance department as they may be the first to identify issues. Management's commitment to this program is a limiting factor to its success. Meetings were reported as being canceled due to scheduling conflicts and others were not scheduled, again due to time constraints.

A facility having an emergency action plan (EAP) is an OSHA requirement (OSHA 2016). A safety consultant who attempted to engage the safety committee in the development process 
reported their client's resistance to giving the committee time to participate. Having the committee's involvement in the EAP development process would have been the ideal buy-in for developing, as well as maintaining, a site-specific plan.

Respondents in this study were not segmented based on industry; rather we looked at the overall effects of applying error reduction. Among the issues raised by respondents was a concern regarding retaliation by the general contractor (GC) and possibly jeopardizing receiving future work because they build-in the additional hours to dedicate to implementing an effective safety and health management system. As this issue is outside the preview of whistleblowing or other retaliation, it's uncertain as to how to best address this issue (OSHA, 2013).

Sixteen of the respondents reported that they had a mentorship program at their worksite. The overall benefits reported included sharing experiences and passing down experience between workers. Peer-to-peer learning is an effective way to transfer occupational safety and health knowledge (O'Neal, 2009). As with other safety initiatives identified in this study, lack of support from senior management was an impediment to having an effective mentoring program.

\subsection{Investing in the Workforce and Employer Responsibility}

Workers need training to understand and adequately control the hazards in their worksite. Local jurisdictions have mandated select courses for workers, including OSHA Outreach Training and Scaffold Training. The responses from this study indicate that workers are receiving mandated safety and health training and a number of them are integrating data from JHA's to develop more effective hazard based training.

The impediments for providing workers health and safety training were similar to those of involving workers in creating JHAs and having safety committees. Some lacked management support in terms of time and money to bring effective programs to fruition. A peripheral issue that students identified during the training and subsequently echoed in the study was the high turnover rate at their worksite. Not having enough senior workers to mentor the next generation may be an impediment to an organization's progress towards an effective OHSMS. Several of the respondents also mentioned that their overall training included skilled-based programs for their temporary workers. In light of the move in many industries to switch to a temporary workforce, it's a positive to see that their needs were also considered (OSHA, 2016).

\section{Conclusion}

Participants who completed the Harwood IIPP training were able to incorporate elements of error reduction to improve their company's safety management system. Scope of this study was limited to identifying how these tools assisted in improving elements of JHA, safety committees, and mentoring programs as well as challenges in implementation. As with all workplace initiatives, without management's support in terms of funding resources and staff time, implementation is challenging. After the initial implementation phase, sustaining the 
effort was seen as a challenge; again, this can be traced back to management as it needs to be reinforced as a high priority.

\section{Limitations}

Data presented from the survey was self-reported and may not reflect every challenge (or success) which existed in implementing an effective injury and illness prevention program.

\section{References}

BLS. (2015). Employer Reported Injuries and Illnesses. Retrieved from http://www.bls.gov/news.release/pdf/osh.pdf

Caruso, Heather M., \& Anita Williams Woolley. (2008). Harnessing the power of emergent interdependence to promote diverse team collaboration. Research on managing groups and teams: Diversity and groups, 11, 245-266. https://doi.org/10.1016/S1534-0856(08)11011-8

Koshy, Koshy, Michael Presutti, \& Mitchel A. Rosen. (2014). Implementing the Hazard Communication Standard final rule: Lessons learned. Journal of Chemical Health and Safety 22(2), 23-31. https://doi.org/10.1016/j.jchas.2014.10.002

LEIGH, PAUL M., "Economic burden of occupational injury and illness in the United States." Milbank Quarterly, 89(4), 728-772. https://doi.org/10.1111/j.1468-0009.2011.00648.x

NYCDOB. (2016). Site safety supervision requirements. Retrieved from https://www1.nyc.gov/nycbusiness/description/site-safety-supervision-requirements\#

NYCDOB. (2015). NYC building approved course requirements. Retrieved from https://www1.nyc.gov/assets/buildings/pdf/40_Hour_Site_Safety_Manager.pdf

NYSDOL. (2009). OSHA 10-hr construction safety and health course. Retrieved from https://labor.ny.gov/workerprotection/publicwork/PDFs/OSHA10Comp.pdf

OSHA. (2012). Injury and Illness Prevention Programs White Paper. Retrieved from https://www.osha.gov/dsg/InjuryIllnessPreventionProgramsWhitePaper.html (access October $15,2016)$

OSHA. (2015). Training Requirements in OSHA Standards. Retrieved from https://www.osha.gov/Publications/osha2254.pdf(October 15, 2106)

OSHA. (2013). Whistleblower protection. Retrieved from https://www.osha.gov/OshDoc/data_General_Facts/whistleblower_rights.pdf (October 15, 2016)

OSHA. (2015). OSHA safety and health management guidelines. Retrieved from https://www.osha.gov/shpmguidelines/SHPM_guidelines.pdf (access October 15, 2016)

OSHA. (2016). Means of egress. Retrieved from https://www.osha.gov/pls/oshaweb/owadisp.show_document?p_id=9726\&p_table=standards (access October 15, 2016) 


\section{Macrothink}

Journal of Management Research

ISSN 1941-899X 2019, Vol. 11, No. 4

OSHA. (2016). Protecting temporary workers. Retrieved from https://www.osha.gov/temp_workers/ (access October 15, 2016).

O'Neil, Judy, \& Victoria J. Marsick. (2009). Peer mentoring and action learning. Adult Learning, 20(1-2), 19. https://doi.org/10.1177/104515950902000105

USDOE. (2007). DOE standard illness and injury prevention surveillance program guidelines. Retrieved from http://energy.gov/sites/prod/files/2013/06/f1/doe-std-1190-2007.pdf (October $15,2016)$

USDOE. (2009). "Human performance improvement handbook, volume 1: concepts and principles" $\quad$ Retrieved from http://energy.gov/sites/prod/files/2013/06/f1/doe-hdbk-1028-2009_volume1.pdf

Vredenburgh, Alison G. (2002). "Organizational safety: which management practices are most effective in reducing employee injury rates?." Journal of safety Research 33.2: 259-276.

\section{Funding}

The curriculum development and training described in this study were funded by the United States Department of Labor (USDOL) Occupational Safety and Health Administration (OSHA) through the Susan Harwood Targeted-Topic Training Grant [Grant number \# SH-24924-SH3]. 